\title{
Motivation and Learning Among Educational Psychology Students in the United States and India*
}

\author{
Anuradhaa Shastri, Jen-Ting Wang \\ The State University of New York, College at Oneonta \\ (SUNY Oneonta), New York, USA
}

\author{
Madhura Kesarkar \\ Shreemati Nathibai Damodar Thackersey Women's \\ University, Mumbai, India
}

\begin{abstract}
Students' motivational orientations and learning strategies are two factors that have consistently been found to be critical in college students' academic achievement. MSLQ (the Motivated Strategies for Learning Questionnaire) developed by Pintrich, Smith, García, and McKeachie (1993) is designed to assess how college students learn and what motivates them. The MSLQ has been utilized extensively in various countries of the world, such as China, Germany, Greece, South Africa, and Thailand. Little is known about its utility when applied to preservice teachers in India. The primary objective of this study was to examine MSLQ scores of 113 preservice teachers from a college in the United States to 127 preservice teachers from a college in India. The research questions included an examination of the relationship between six motivational subscales and the nine subscales of learning strategies amongst students enrolled in Educational Psychology courses. On the whole, the pattern of correlations among MSLQ scales indicates similarities in motivational beliefs and learning strategies for both the US and India samples providing evidence for the utility of the MSLQ to preservice teachers in India.
\end{abstract}

Keywords: preservice teachers, motivation, learning, empirical study

Students' motivational orientations and learning strategies are two factors that have consistently been found to be critical in college students' academic achievement (Langley, 2007). MSLQ (the Motivated Strategies for Learning Questionnaire) developed by Pintrich et al. (1993) is designed to assess how college students learn and what motivates them. A recent meta-analytic review stated that "MSLQ is a reasonably reliable measure of constructs, some of which exhibit meaningful relationships with college academic performance" (Credé \& Phillips, 2011, pp. 342-343).

The MSLQ has been utilized extensively in various countries of the world, such as China (e.g., Rao, Moely, \& Sachs, 2000), Germany (e.g., Neber \& Heler, 2002), Greece (e.g., Andreou \& Metallidou, 2004), South Africa (e.g., M. Watson, McSorley, Foxcroft, \& A. Watson, 2004), and Thailand (e.g., Suksamram, 2003). However, little is known about its utility when applied to preservice teachers in India. The study by Bhattacharyya $(2004 ; 2007)$ is among the very few cited in the literature.

\footnotetext{
*Acknowledgements: The authors wish to express their gratitude to their colleagues Brian D. Beitzel for his helpful comments on an earlier version of this article and Diana Moseman, for the technical assistance in the online administration of MSLQ.

Anuradhaa Shastri, Associate Professor, Department of Educational Psychology, Counseling, and Special Education, The State University of New York, College at Oneonta (SUNY Oneonta).

Jen-Ting Wang, Associate Professor, Department of Mathematics, Computer Science, and Statistics, The State University of New York, College at Oneonta (SUNY Oneonta).

Madhura Kesarkar, Director, Board of College and University Development, Shreemati Nathibai Damodar Thackersey Women's University.
} 


\section{Purpose of the Study}

The purpose of the present study was to compare the motivational orientations and learning strategies of preservice teachers enrolled in educational psychology courses in two teacher education programs, State University of New York, College at Oneonta, in the United States and Shreemati Nathibai Damodar Thackersey Women's University, Mumbai, India. The three basic research questions were as follows:

(1) How are the six motivational subscales related to the nine subscales of learning strategies amongst students in the United States and India?

(2) How are the three motivational components related to the three components of learning strategies amongst students in the United States and India? Since this question combines the subscales in domains, it would lend itself to an emergence of any patterns that may be present.

(3) Are there significant differences between students in the United States and India on six motivational subscales and the nine subscales of learning strategies?

\section{Theoretical Framework}

\section{MSLQ}

MSLQ is based on the social cognitive view of motivation and self-regulated learning (Pintrich, 2003). According to this framework, students' motivation is related to their ability to self-regulate their learning activities. Motivation and learning strategies are not regarded as static traits of the learner, but rather that "motivation is dynamic and contextually bound and that learning strategies can be learned and brought under the control of the student" (Duncan \& McKeachie, 2005, p.117).

The MSLQ is comprised of 15 subscales divided into two sections-the motivation section and the learning strategies section.

\section{MSLQ Motivation Section}

The motivational scales include a total of 31 items and are based on three motivational constructs: expectancy, value beliefs, and affect (Pintrich, 1988a; 1988b; 1989). The self-efficacy and control beliefs for learning subscales seek to assess expectancy. The self-efficacy subscale includes expectancy for success that is specific to task performance and confidence in one's ability to complete a task successfully. Control beliefs for learning subscale pertains to students' beliefs that outcomes are a consequence of one's own effort, rather than external chance factors like luck. Value components focus on the reasons students engage in an academic task and include three subscales. The intrinsic goal orientation subscale taps learning and mastery; extrinsic goal orientation subscale has a focus on grades and approval from others; and task value beliefs subscale pertains to the student's judgments of the importance and usefulness of course content. The third motivational construct is affect. It includes the test anxiety subscale and refers to the worries over taking exams in that course.

\section{MSLQ Learning Strategies Section}

The learning strategies section comprises of 50 questions pertaining to three general types of strategies: cognitive, metacognitive, and resource management. Cognitive strategies are assessed with four subscales and pertain to students' use of basic and complex strategies for processing of information from texts and lectures. The second category is metacognitive control strategies, measured by one subscale related to the use of strategies that help students monitor their own mental processes and adjust them as needed. The third category is resource management and includes four subscales pertaining to students' ability to manage their time and 
study environment, to persist at an academic task, to study with peers, and to seek help either from instructors or peers when needed.

In summary, the 15 subscales of the MSLQ assess student motivation pertaining to a course and the use of learning strategies within that course. The structure and example items for the MSLQ are given in Table 1.

Table 1

\begin{tabular}{|c|c|c|c|c|}
\hline Section & Sub-section & Scales & \#items & Example item \\
\hline \multirow[t]{6}{*}{$\begin{array}{l}\text { Motivational } \\
\text { scales }\end{array}$} & \multirow[t]{2}{*}{$\begin{array}{l}\text { Value } \\
\text { components }\end{array}$} & Intrinsic goal orientation & 4 & $\begin{array}{l}\text { In a class like this, I prefer course material that really } \\
\text { challenges me so that I can learn new things. }\end{array}$ \\
\hline & & Extrinsic goal orientation & 4 & $\begin{array}{l}\text { Getting a good grade in this class is the most satisfying } \\
\text { thing for me right now. }\end{array}$ \\
\hline & \multirow[t]{3}{*}{$\begin{array}{l}\text { Expectancy } \\
\text { component }\end{array}$} & Task value & 6 & $\begin{array}{l}\text { It is important for me to learn the course material in this } \\
\text { class. }\end{array}$ \\
\hline & & Control beliefs & 4 & $\begin{array}{l}\text { If I study in the appropriate ways, then I will be able to } \\
\text { learn the material in this course. }\end{array}$ \\
\hline & & $\begin{array}{l}\text { Self-efficacy for learning } \\
\text { and performance }\end{array}$ & 8 & I believe I will receive an excellent grade in this class. \\
\hline & $\begin{array}{l}\text { Affective } \\
\text { component }\end{array}$ & Test anxiety & 5 & When I take tests I think of the consequences of failing. \\
\hline \multirow[t]{9}{*}{$\begin{array}{l}\text { Learning } \\
\text { strategies scales }\end{array}$} & $\begin{array}{l}\text { Cognitive and } \\
\text { Metacognitive } \\
\text { strategies }\end{array}$ & Rehearsal & 4 & $\begin{array}{l}\text { When I study for this class, I practice saying the material } \\
\text { to myself over and over. }\end{array}$ \\
\hline & & Elaboration & 6 & $\begin{array}{l}\text { When I study for this class, I pull together information } \\
\text { from different sources, such as lectures, readings, and } \\
\text { discussions. }\end{array}$ \\
\hline & & Organization & 4 & $\begin{array}{l}\text { When I study the readings for this course, I outline the } \\
\text { material to help me organize my thoughts. }\end{array}$ \\
\hline & & Critical thinking & 5 & $\begin{array}{l}\text { I often find myself questioning things I hear or read in this } \\
\text { course to decide if I find them convincing. }\end{array}$ \\
\hline & & $\begin{array}{l}\text { Metacognitive } \\
\text { self-regulation }\end{array}$ & 12 & $\begin{array}{l}\text { When reading for this course, I make up questions to help } \\
\text { focus my reading. }\end{array}$ \\
\hline & \multirow[t]{4}{*}{$\begin{array}{l}\text { Resource } \\
\text { management } \\
\text { strategies }\end{array}$} & $\begin{array}{l}\text { Time and study } \\
\text { environment }\end{array}$ & 8 & $\begin{array}{l}\text { I usually study in a place when I can concentrate on my } \\
\text { course work. }\end{array}$ \\
\hline & & Effort regulation & 4 & $\begin{array}{l}\text { I work hard to do well in this class even if I don't like } \\
\text { what we are doing. }\end{array}$ \\
\hline & & Peer learning & 3 & $\begin{array}{l}\text { When studying for this course, I often try to explain the } \\
\text { material to a classmate or a friend. }\end{array}$ \\
\hline & & Help seeking & 4 & $\begin{array}{l}\text { I ask the instructor to clarify concept I don't understand } \\
\text { well. }\end{array}$ \\
\hline
\end{tabular}

Source: Credé \& Alison (2011). A meta-analytic review of the Motivated Strategies for Learning Questionnaire. Learning and Individual Differences, 21, 337-346.

\section{Method}

The data presented here were gathered from preservice teachers enrolled in educational psychology courses in two teacher education programs, State University of New York, College at Oneonta, in the United States and Shreemati Nathibai Damodar Thackersey Women's University, Mumbai, India. The US sample consisted of 113 female students and the sample from India consisted of 127 female students.

\section{Teacher Education Program at the State University of New York, College at Oneonta (SUNY Oneonta)}

SUNY Oneonta was founded in 1889 as a normal school with approximately 200 students. Primarily a teacher training college for 60 years, the College established a three-year education program in 1923 and awarded its first Bachelor of Education degrees in 1942 (SUNY Oneonta, Self-Study Report, 2013). In 1948, 
the College became a charter member of SUNY and today is a 4-year, Master's comprehensive institution in upstate New York. The College enrolls nearly 6,000 students in 69 undergraduate majors, nine graduate programs, and several specialized certificate programs. The three academic departments, namely Elementary Education and Reading, Secondary Education, and Educational Psychology, Counseling, and Special Education serve the largest number of majors in the institution, completing one of the several degree or certificate programs offered in education.

\section{Teacher Education Program at Shreemati Nathibai Damodar Thackersey Women's University (SNDTWU)}

SNDTWU is the first women's university in India as well as in South-East Asia. The university was founded by Maharshi Dr. Dhondo Keshav Karve in 1916 for a noble cause of women's education. The first five women graduated in 1921 and today SNDTWU has an enrollment of over 70,000 students (retrieved from http://sndt.ac.in/default.htm). The Bachelor's in Education (B.Ed.) is a one-year post-graduate 48 credit hours program. Approximately 11,000 students enroll every year in the B.Ed. program. Of these approximately 460 are in Mumbai colleges from where the sample was drawn.

Both the programs at SUNY Oneonta and SNDTWU have the following common elements: (1) foundation courses on education; (2) teaching methodology; and (3) practicum. One major difference is that teacher education at SUNY Oneonta is a four-year undergraduate degree and at SNDTWU students first complete a three-year bachelor's degree program followed by a one-year bachelor's degree in education. The samples for the present study were drawn from Educational Psychology courses that focused on learning and motivation theories. These courses at both the institutions had similar content that included understanding and developing the learner, teaching learning processes from behavioral, cognitive, humanistic, and constructive perspectives.

\section{Data Sources}

The MSLQ includes 81 self-report items scored on a 7-point Likert scale, from 1 ("Not at all true of me") to 7 ("Very true of me"). As per MSLQ scoring instructions (Pintrich et al., 1991), scoring of the negatively phrased items was reversed so that higher scores reflected a more positive motivational orientation and use of learning strategies. Scores for the individual subscales were computed by taking the mean of the items within that subscale.

\section{Results and Discussion}

The first question of the study concerned the relations between the six motivational subscales and the nine subscales of learning strategies for the two samples. Table 2 displays the zero-order correlations for the motivational and learning subscales. For both the US and India groups, the value scales (i.e., intrinsic goal orientation, extrinsic goal orientation, and task value), and the expectancy scales (i.e., self-efficacy and control beliefs for learning) were all positively correlated with one another and were statistically significant. The correlation coefficients $(r \mathrm{~s})$ ranged from 0.200 to 0.584 , with an exception of no linear correlation between intrinsic and extrinsic goal orientation for the US group.

Most of the cognitive scales (i.e., rehearsal, elaboration, organization, and critical thinking), metacognitive scales (i.e., planning, monitoring, and regulating), and resource management strategies subscales (i.e., managing time and study environment, regulation of their own effort, peer learning, and help seeking) were found to be positively correlated with one another for at least one group, and statistically significant. The $r$ s 
ranged from 0.182 to 0.745 . Additionally, there was a statistically significant positive correlation between organization and effort regulation in both groups ( 0.505 for US and 0.294 for India). One subscale that clearly stands out is peer learning which is seen to be statistically significant with cognitive, metacognitive, and resource management strategies for both the groups suggesting a similarity between them.

Table 2

Subscale Correlations

\begin{tabular}{|c|c|c|c|c|c|c|c|c|c|c|c|c|c|c|c|}
\hline & & $\begin{array}{l}\text { extrinsic } \\
\text { goal }\end{array}$ & $\begin{array}{l}\text { task } \\
\text { value }\end{array}$ & $\begin{array}{l}\text { control } \\
\text { beliefs }\end{array}$ & $\begin{array}{l}\text { self } \\
\text { efficacy }\end{array}$ & $\begin{array}{l}\text { test } \\
\text { anxiety }\end{array}$ & rehearsal & elaboration & organization & $\begin{array}{l}\text { critical } \\
\text { thinking }\end{array}$ & $\begin{array}{l}\text { meta } \\
\text { cognition }\end{array}$ & $\begin{array}{l}\text { peer } \\
\text { learning }\end{array}$ & $\begin{array}{l}\text { effort } \\
\text { regulation }\end{array}$ & $\begin{array}{l}\text { help } \\
\text { seeking }\end{array}$ & $\begin{array}{l}\text { time and } \\
\text { study } \\
\text { environ. }\end{array}$ \\
\hline \multirow{2}{*}{ Intrinsic goal } & USA & 0.047 & $0.296^{* *}$ & $0.387^{* *}$ & $0.397^{* *}$ & $0.446^{* *}$ & $0.546^{* *}$ & $0.268^{* *}$ & $0.390^{* *}$ & $0.432^{* * *}$ & $0.373^{* *}$ & $0.680^{* *}$ & $0.428^{* * *}$ & $0.774^{* * *}$ & $0.670^{* * *}$ \\
\hline & India & $0.210^{*}$ & $0.380^{* * *}$ & $0.202^{*}$ & $0.244^{* *}$ & $0.253^{* *}$ & $0.189^{*}$ & $0.235^{*}$ & 0.129 & $0.237^{* *}$ & $0.306^{* *}$ & $0.258^{* *}$ & 0.045 & -0.114 & 0.134 \\
\hline \multirow[t]{2}{*}{ Extrinsic goal } & USA & & $0.327^{* * *}$ & $0.408^{8 *}$ & $0.251^{* *}$ & $0.428^{* *}$ & 0.104 & $0.508^{* *}$ & $0.190^{*}$ & $0.249^{* * *}$ & $0.382^{* *}$ & 0.102 & 0.014 & 0.163 & 0.114 \\
\hline & India & & $0.214^{*}$ & $0.195^{*}$ & $0.404^{* *}$ & $0.288^{* *}$ & 0.121 & 0.086 & 0.162 & 0.101 & $0.229^{* * *}$ & 0.077 & 0.100 & $-0.180^{*}$ & 0.019 \\
\hline \multirow{2}{*}{ Task value } & USA & & & $0.304^{* *}$ & $0.584^{* *}$ & $0.325^{* *}$ & $0.315^{* *}$ & $0.454^{* *}$ & $0.544^{* *}$ & $0.552^{* *}$ & $0.544^{* *}$ & $0.368^{* *}$ & $0.490^{* *}$ & $0.369^{* *}$ & $0.376^{* *}$ \\
\hline & India & & & $0.286^{* *}$ & $0.336^{* *}$ & -0.030 & $0.207^{*}$ & $0.191^{*}$ & $0.250^{* *}$ & $0.240^{* * *}$ & $0.289^{* * *}$ & 0.111 & 0.069 & -0.067 & 0.121 \\
\hline \multirow{2}{*}{ Control beliefs } & USA & & & & $0.200^{*}$ & $0.495^{* *}$ & $0.407^{* *}$ & $0.477^{* *}$ & $0.400^{* *}$ & $0.469^{* * *}$ & $0.438^{* *}$ & $0.427^{* *}$ & $0.422^{* * *}$ & $0.427^{* *}$ & $0.488^{* *}$ \\
\hline & India & & & & $0.232^{* *}$ & 0.125 & $0.229^{* *}$ & 0.037 & -0.003 & 0.094 & $0.206^{*}$ & 0.046 & 0.119 & -0.108 & -0.126 \\
\hline \multirow{2}{*}{ Self efficacy } & USA & & & & & 0.128 & $0.284^{* *}$ & $0.249^{* *}$ & $0.288^{* *}$ & $0.360^{* * *}$ & $0.494^{* *}$ & $0.294^{* *}$ & 0.207 & $0.246^{* *}$ & 0.103 \\
\hline & India & & & & & -0.033 & $0.284^{* *}$ & $0.215^{*}$ & $0.277^{* *}$ & $0.245^{* *}$ & $0.259^{* * *}$ & 0.018 & -0.073 & $-0.237^{* *}$ & $0.222^{*}$ \\
\hline \multirow{2}{*}{ Test anxiety } & USA & & & & & & $0.421^{* *}$ & $0.440^{* *}$ & $0.498^{* * *}$ & $0.424^{* *}$ & $0.336^{* *}$ & $0.564^{* * *}$ & $0.530^{* *}$ & $0.527^{* *}$ & $0.566^{* *}$ \\
\hline & India & & & & & & 0.086 & -0.133 & -0.011 & -0.091 & -0.015 & 0.171 & $0.182^{*}$ & -0.169 & $-0.189^{*}$ \\
\hline \multirow{2}{*}{ Rehearsal } & USA & & & & & & & 0.086 & $0.539^{* *}$ & $0.411^{* *}$ & $0.444^{* *}$ & $0.725^{* *}$ & $0.418^{* *}$ & $0.590^{* *}$ & $0.469^{* * *}$ \\
\hline & India & & & & & & & $0.373^{* *}$ & $0.482^{* *}$ & $0.543^{* * *}$ & $0.511^{* *}$ & $0.278^{* *}$ & 0.150 & 0.029 & $0.186^{*}$ \\
\hline \multirow{2}{*}{ Elaboration } & USA & & & & & & & & $0.226^{*}$ & $0.529^{* * *}$ & $0.516^{* *}$ & $0.215^{*}$ & $0.356^{* *}$ & $0.439^{* * *}$ & $0.426^{* *}$ \\
\hline & India & & & & & & & & $0.468^{* *}$ & $0.414^{* * *}$ & $0.550^{* * *}$ & $0.350^{* m *}$ & 0.152 & 0.029 & $0.199^{*}$ \\
\hline \multirow{2}{*}{ Organization } & USA & & & & & & & & & $0.275^{* * *}$ & $0.392^{* *}$ & $0.558^{* *}$ & $0.505^{* *}$ & $0.539^{* * *}$ & $0.540^{* * *}$ \\
\hline & India & & & & & & & & & $0.440^{* * *}$ & $0.580^{* *}$ & $0.291^{* *}$ & $0.294^{* *}$ & $0.183^{*}$ & 0.053 \\
\hline \multirow{2}{*}{ Critical thinking } & USA & & & & & & & & & & $0.614^{* *}$ & $0.454^{* *}$ & $0.460^{* *}$ & $0.510^{* * *}$ & $0.499^{* * *}$ \\
\hline & India & & & & & & & & & & $0.492^{* * *}$ & $0.246^{* * *}$ & 0.049 & 0.075 & $0.305^{* *}$ \\
\hline \multirow{2}{*}{ Meta cognition } & USA & & & & & & & & & & & $0.415^{* *}$ & $0.406^{* * *}$ & $0.521^{* *}$ & $0.358^{* *}$ \\
\hline & India & & & & & & & & & & & $0.329^{* *}$ & $0.254^{* * *}$ & 0.119 & 0.137 \\
\hline \multirow{2}{*}{ Peer learning } & USA & & & & & & & & & & & & $0.510^{* *}$ & $0.735^{* *}$ & $0.633^{* *}$ \\
\hline & India & & & & & & & & & & & & $0.330^{*}$ & $0.312^{* *}$ & $0.207^{* *}$ \\
\hline \multirow{2}{*}{$\begin{array}{l}\text { Effort } \\
\text { regulation }\end{array}$} & USA & & & & & & & & & & & & & $0.471^{* * *}$ & $0.595^{* *}$ \\
\hline & India & & & & & & & & & & & & & $0.203^{*}$ & $-0.176^{*}$ \\
\hline \multirow{2}{*}{ Help seeking } & USA & & & & & & & & & & & & & & $0.745^{* *}$ \\
\hline & India & & & & & & & & & & & & & & 0.163 \\
\hline
\end{tabular}

Notes. ${ }^{* *}$ Correlation is significant at the 0.01 level (2-tailed); ${ }^{*}$ Correlation is significant at the 0.05 level (2-tailed).

Moderate and positive correlations were found between test anxiety and the use of cognitive, metacognitive, and resource management strategies in the US group, implying that students who were more anxious about tests were more likely to use all of the three components of learning strategies than those who were less anxious, though no significant linear correlations were found in India group.

The second question of this study concerned the relations between the three motivational components and the three components of learning strategies for the two groups. Table 3 displays the zero-order correlations for the motivational and learning components. Moderately strong positive correlations were found between value beliefs, expectancy beliefs, use of cognitive strategies, and metacognitive strategies. This implies that students 
with reasons to engage in an academic task, and beliefs that they can accomplish the task that were more likely to use learning strategies. However, resource management strategies were significant for the US group but not for the India group.

Test anxiety was significantly positively correlated with all other domains for the US group, while it was significant only with value beliefs for the India group as seen in Table 3.

Table 3

Domain Correlation

\begin{tabular}{|c|c|c|c|c|c|c|}
\hline & & Value beliefs & $\begin{array}{l}\text { Expectancy } \\
\text { beliefs }\end{array}$ & Test anxiety & $\begin{array}{l}\text { Cognitive } \\
\text { strategies }\end{array}$ & Meta cognitive \\
\hline \multirow{2}{*}{ Expectancy beliefs } & USA & $0.717^{* *}$ & & & & \\
\hline & India & $0.473^{* *}$ & & & & \\
\hline \multirow{2}{*}{ Test anxiety } & USA & $0.578^{* *}$ & $0.415^{* *}$ & & & \\
\hline & India & $0.252^{* *}$ & 0.074 & & & \\
\hline \multirow{2}{*}{ Cognitive strategies } & USA & $0.766^{* *}$ & $0.673^{* *}$ & $0.626^{* *}$ & & \\
\hline & India & $0.320^{* *}$ & $0.268^{* *}$ & -0.037 & & \\
\hline \multirow{2}{*}{ Meta cognitive } & USA & $0.622^{* *}$ & $0.599^{* *}$ & $0.336^{* *}$ & $0.694^{* *}$ & \\
\hline & India & $0.383^{* *}$ & $0.288^{* *}$ & -0.015 & $0.692^{* *}$ & \\
\hline \multirow{2}{*}{ Resource management } & USA & $0.644^{* *}$ & $0.510^{* *}$ & $0.650^{* *}$ & $0.793^{* *}$ & $0.521^{* *}$ \\
\hline & India & 0.091 & -0.047 & 0.004 & $0.399^{* *}$ & $0.336^{* *}$ \\
\hline
\end{tabular}

Note. ${ }^{* *}$ Correlation is significant at $1 \%$ level (2-tailed).

The third question of this study concerned the differences between the two groups on six motivational and nine learning strategies subscales. Table 4 shows the mean scores of each category in motivation scales for both groups. The India group had significantly higher means in all categories except test anxiety, which indicates that students in India group were more motivated in studying for the course with more confidence in tests than those in US.

Table 4

Comparisons on the Motivation Scales (USA-India)

\begin{tabular}{llll}
\hline Motivation scales & USA mean (s.d.) & India mean (s.d.) & Mean difference \\
\hline 1. Intrinsic goal orientation & $4.82(0.87)$ & $5.35(0.90)$ & $-0.53^{* *}$ \\
2. Extrinsic goal orientation & $5.23(0.93)$ & $5.94(0.90)$ & $-0.71^{* *}$ \\
3. Task value & $5.13(0.85)$ & $5.59(0.77)$ & $-0.46^{* *}$ \\
4. Control of learning beliefs & $4.79(0.86)$ & $5.05(1.14)$ & $-0.26^{*}$ \\
5. Self-efficacy & $4.87(0.86)$ & $5.46(0.82)$ & $-0.59^{* *}$ \\
6. Test anxiety & $4.88(0.77)$ & $4.24(1.18)$ & $0.64^{* *}$ \\
\hline
\end{tabular}

Note. ${ }^{* *}$ Significant at $1 \%$ level; ${ }^{*}$ Significant at $5 \%$ level.

Comparisons of mean scores for categories in learning strategy scales are shown in Table 5. Students in India had significantly higher mean scores in three cognitive strategies categories but lower in rehearsal. Students in the US group had a higher mean score in effort management indicating that they were more likely to put in efforts than students in India. However, there is no difference between the two groups in the use of metacognitive self-regulation strategies as well as the management of time and study environment. In summary, students were more motivated in the India group than in US, while the differences in the use of learning strategies were not as straight forward. 
These results could be compared to those found in Bhattacharyya (2004), where in the India sample demonstrated significantly higher self-ratings in the motivational variables of intrinsic goal orientation, extrinsic goal orientation, and task value and in the learning strategy variables of elaboration, organization, critical thinking, metacognitive self-regulation, peer-learning, and help seeking. Students in the US group demonstrated higher self-ratings only in the learning strategy variable of effort regulation. There were no significant difference in the means and standard deviations of the motivational variables of control beliefs, self-efficacy for learning and performance, and test anxiety or the learning strategy variables of rehearsal and time and study environment.

Table 5

Comparisons on the Learning Strategy Scales (USA-India)

\begin{tabular}{lllc}
\hline Learning strategy scales & USA mean (s.d.) & India mean (s.d.) & Mean difference \\
\hline 1. Rehearsal & $5.76(0.80)$ & $5.33(0.94)$ & $0.43^{* *}$ \\
2. Elaboration & $4.34(0.92)$ & $5.53(0.72)$ & $-1.19^{* *}$ \\
3. Organization & $5.06(0.76)$ & $5.68(0.86)$ & $-0.62^{* *}$ \\
4. Critical thinking & $4.52(0.79)$ & $5.04(0.76)$ & $-0.52^{* *}$ \\
5. Metacognitive self-regulation & $5.10(0.71)$ & $5.06(0.61)$ & 0.04 \\
6. Time and study environment & $4.75(0.87)$ & $4.65(0.78)$ & 0.10 \\
7. Effort regulation & $5.02(0.95)$ & $4.59(0.93)$ & $0.43^{* *}$ \\
8. Peer learning & $5.26(0.83)$ & $5.45(1.00)$ & -0.19 \\
9. Help seeking & $5.03(0.77)$ & $5.10(0.83)$ & -0.07 \\
\hline
\end{tabular}

Note. ${ }^{* *}$ Significant at $1 \%$ level.

\section{Significance of the Study}

The primary objective of the present study was to examine similarities and differences in motivational orientations and learning strategies of preservice teachers in the United States and India. On the whole, the correlations among MSLQ scales indicate that they represent an array of different motivational beliefs and self-regulatory strategies that can be distinguished from one another on both conceptual and empirical grounds.

However, when we examine the differences between the subscales for the two groups, a different picture emerges. Students in India group were more motivated and had lower test anxiety compared to those in the US. The differences on the learning strategy subscales are not as clear cut. The US group appears to use rehearsal strategies more than the India group. On the other hand, the use of deeper processing strategies like elaboration, organization and critical thinking are higher in the India group. Strangely there is no difference between the two groups in the use of metacognitive self-regulation strategies as well as the management of time and study environment. However, students in the US group show higher scores at effort regulation, i.e., persistence at difficult tasks. One subscale that clearly stands out is peer learning which is seen to be statistically significant with cognitive, metacognitive, and resource management strategies for both the groups suggesting a similarity between them.

The major strength of this investigation is that it provides evidence for the utility of the MSLQ to preservice teachers in India. Many researchers have suggested that more cross-cultural studies should be conducted in order to gain a comprehensive view of how learning and motivational factors interact (e.g., Bhattacharyya, 2004, 2007; Credé \& Phillips, 2011). The present study extends this line of research. 
The major limitations of this study are that the participants are all females and from educational psychology courses. Further studies are needed to examine whether these results are generalizable to male students and from a wider range of academic disciplines. Moreover, the questions of international comparability have been addressed using self-report data. The contextual meanings and functions of motivational and self-regulation constructs would need to be examined perhaps using qualitative measures like student conversations or focus groups.

\section{References}

Andreou, E., \& Metallidou, P. (2004). The relationship of academic and social cognition to behavior in bullying situations among Greek primary school children. Educational Psychology, 24, 27-41.

Bhattacharyya, S. (2004). Dynamics of motivation and self-regulation among college pre-service teachers: A cross-cultural perspective (Unpublished doctoral dissertation, the University of Memphis).

Bhattacharyya, S. (2007). Cross-cultural motivation and self-regulation. Academic Exchange, Summer 2007, 11(2), 16-20.

Credé, M., \& Alison, P. L. (2011). A meta-analytic review of the Motivated Strategies for Learning Questionnaire. Learning and Individual Differences, 21, 337-346.

Duncan, T. G., \& McKeachie, W. J. (2005). The making of the Motivated Strategies for Learning Questionnaire. Educational Psychologist, 40, 117-128.

Langley, S. R., II (2007). Identifying self-regulatory factors that influence the academic achievement motivation of underprepared college students (Unpublished doctoral dissertation, University of Minnesota).

Neber, H., \& Heller, K. A. (2002). Evaluation of a summer-school program for highly gifted secondary-school students: The German Pupils Academy. European Journal of Psychological Assessment, 18, 214-228.

Pintrich, P. R. (1988a). A process-oriented view of student motivation and cognition. In J. Stark, \& L. Mets (Eds.), Improving teaching and learning through research: New directions for institutional research (Vol. 57, pp. 65-79). San Francisco: Jossey-Bass.

Pintrich, P. R. (1988b). Student learning and college teaching. In R. E. Young, \& K. E. Eble (Eds.), College teaching and learning: Preparing for new commitments. New directions for teaching and learning (Vol. 33, pp. 71-86). San Francisco: Jossey-Bass.

Pintrich, P. R. (1989). The dynamic interplay of student motivation and cognition in the college classroom. In C. Ames, \& M. L. Maehr (Eds.), Advances in motivation and achievement: Motivation-enhancing environments (Vol. 6, pp. 117-160). Greenwich, C.T.: JAI.

Pintrich, P. R. (2003). A motivational science perspective on the role of student motivation in learning and teaching contexts. Journal of Educational Psychology, 95(4), 667-686.

Pintrich, P. R., Smith, D. A. F., García, T., \& McKeachie, W. J. (1991). A manual for the use of the Motivated Strategies for Learning Questionnaire (MSLQ). Ann Arbor: University of Michigan, National Center for Research to Improve Postsecondary Teaching and Learning.

Pintrich, P. R., Smith, D. A. F., García, T., \& McKeachie, W. J. (1993). Reliability and predictive validity of the Motivated Strategies for Learning Questionnaire (MSLQ). Educational and Psychological Measurement, 53, 801-813.

Rao, N., Moely, B. E., \& Sachs, J. (2000). Motivational beliefs, study strategies, and mathematics attainment in high- and lowachieving Chinese secondary school students. Contemporary Educational Psychology, 25, 287-316.

SUNY Oneonta. (2013). Self-Study Report. Retrieved from http://www.oneonta.edu/middlestates/documents/SelfStudyReport 2013CompleteFinal.Campus.pdf

Suksamram, A. (2003). Factors related to self-regulated learning of the first-year nursing students. (Unpublished doctoral dissertation, Mahidol University, Thailand).

Watson, M., McSorley, M., Foxcroft, C., \& Watson, A. (2004). Exploring the motivation orientation and learning strategies of first year university learners. Tertiary Education and Management, 10, 193-207. 